Materiales de Construcción

Vol. 69, Issue 334, April-June 2019, e183

ISSN-L: 0465-2746

https://doi.org/10.3989/mc.2019.06018

\title{
Study of the expansion of cement mortars manufactured with Ladle Furnace Slag LFS
}

\author{
A. Rodríguez $\bowtie$, I. Santamaría-Vicario, V. Calderón, C. Junco, J. García-Cuadrado \\ Departamento de Construcciones Arquitectónicas e Ingeniería de la Construcción y del Terreno \\ Escuela Politécnica Superior Universidad de Burgos (Burgos. Spain) \\ \arsaizmc@ubu.es
}

Received 14 June 2018

Accepted 14 February 2019

Available on line 04 April 2019

\begin{abstract}
Industrial by-products generated in the steel manufacturing are successfully used as raw materials in the production of construction materials. However, steel slags, due to their nature and composition, can cause undesirable side-effects in mortars and concretes. The reactive components of LFS and EAFS can affect the stability of the cement matrix. This situation may be prevented by an adequate pre-treatment of slag stabilization and a study of the possible reactions within its mineralogical components, to ensure the stability of the slag over time. In this work, an experimental process is shown to evaluate the behaviour of LFS under adverse environmental conditions when used as aggregates in the manufacture of cement mortars for masonry, such as the presence of humidity, high temperatures $\left(80^{\circ} \mathrm{C}\right)$ and possible alkali-silica and alkali-silicate reactions. The results show an acceptable behaviour under normal environmental conditions $\left(20^{\circ} \mathrm{C}\right)$. However, the formation crystalline acicular structures were observed under high temperatures $\left(80^{\circ} \mathrm{C}\right)$ and in the presence of humidity, which degraded the internal structure of the mortars manufactured with LFS.
\end{abstract}

KEYWORDS: Mortar; LFS; Steelmaking slags; Expansion; Reactivity

Citation/Citar como: Rodríguez, A.; Santamaría-Vicario, I.; Calderón, V.; Junco, C.; García-Cuadrado, J. (2019) Study of the expansion of cement mortars manufactured with Ladle Furnace Slag LFS. Mater. Construcc. 69 [334], e183 https://doi.org/10.3989/mc.2019.06018

RESUMEN: Estudio de la expansividad de los morteros de cemento fabricados con escoria blanca de horno cuchara LFS. Los subproductos industriales producidos en la fabricación de acero están siendo utilizados con éxito como materias primas en la producción de materiales de construcción. Sin embargo, las escorias de acero, debido a su naturaleza y composición, pueden causar efectos secundarios indeseables en morteros y hormigones. No obstante, las escorias de acería pueden causar efectos secundarios no deseados en los morteros y hormigones. Los componentes reactivos de las LFS y EAFS pueden afectar a la estabilidad de la matriz de cemento. Esta situación se puede prevenir mediante un adecuado tratamiento previo de estabilización de la escoria y de un estudio de las posibles reacciones de sus componentes mineralógicos, para asegurar su estabilidad en el tiempo. En este trabajo se muestra un proceso experimental para valorar el comportamiento de las escorias blancas de Horno Cuchara LFS cuando se utilizan como áridos en la fabricación de morteros de cemento para albañilería, comprobando su comportamiento en condiciones ambientales adversas, tales como la presencia de humedad, altas temperaturas $\left(80^{\circ} \mathrm{C}\right)$ y las posibles reacciones álcali-sílice y álcali-silicato, con el objetivo de determinar su viabilidad en el diseño de morteros. Los resultados muestran un comportamiento adecuado en condiciones de ambientales normales $\left(20^{\circ} \mathrm{C}\right)$. Sin embargo, a altas temperaturas $\left(80^{\circ} \mathrm{C}\right)$ y en presencia de humedad se desarrollan estructuras cristalinas aciculares que provocan la rotura de la estructura interna de los morteros fabricados con LFS.

PALABRAS CLAVE: Mortero; LFS; Escorias de acería; Expansión; Reactividad

ORCID ID: A. Rodríguez (https://orcid.org/0000-0002-3607-2167); I. Santamaría-Vicario (https://orcid.org/00000002-3576-2107); V. Calderón (https://orcid.org/0000-0001-6863-5473); C. Junco (https://orcid.org/0000-0002-95296435); J. García-Cuadrado (https://orcid.org/0000-0001-6635-7692).

Award-winning paper at International Congress on Construction and Building Research - COINVEDI 2017. San Cristobal de La Laguna (Tenerife), 14-15 December, 2017

Copyright: (C) 2019 CSIC. This is an open-access article distributed under the terms of the Creative Commons Attribution 4.0 International (CC BY 4.0) License. 


\section{INTRODUCTION}

Social awareness arising from respect for the environment and for the sustainability of economic activities is making a change in consumer patterns possible, opting for the recycling and the valuation of waste products generated by industrial activities and for their use as raw materials in the production of other consumer goods $(1,2)$. This is the so-called "circular economy", an option that permits the optimization of natural resources, avoiding their overexploitation. In the context of the European Union, it is a real effort for the sustainable management of economic activities $(3,4)$.

One of the industrial activities that has had most impact on the environment is the production of steel, mainly due to the high consumption of energy and natural resources and due to the considerable volume of waste that it generates $(5,6)$. Nevertheless, technological developments have led to reductions in the energetic consumption of steel manufacturing processes and to the use of scrap iron and other metallic wastes with quantifiable amounts of iron as raw materials. However, the quantities of slag generated in the various steel manufacturing and refining processes continue to increase, accumulating in dumping sites, contaminating the ground and leaving unsightly impacts on the landscape that are difficult to remove (7).

The European Union is one of the major global steel producers. The most widely used technology in Europe is the Blast Furnace and Oxygen Converter process, in which Blast Furnace slag BFS is generated. However, steel-plant technologies in Spain are principally Electric Arc Furnaces that produce EAFS, while LFS is produced in the Ladle Furnace refining process.

The efforts of Materials Research Groups have for some years been persistently searching for an alternative use for LFS and EAFS (8-12). Traditionally, EAFS has been used as aggregate in the construction of bases and sub-bases for roadways (13) and in bituminous binders for roadways $(14,15)$.

In the area of construction materials, EAFS dosed with conventional aggregates have been used in the manufacture of structural concretes with equivalent properties to those of conventional concretes (16-18). The finer fractions, either separately or jointly with LFS, have successfully been used in the manufacture of masonry mortars (19-21).

Other uses have been for material correction in soil stabilization (22), in the construction of bacterial filters for the filtering of waste waters (23) and as a raw material in the manufacture of Portland cement (24).

Nevertheless, the problems that slags generate are related with the secondary effects produced by the hydratable components that mainly contain noncombined $\mathrm{CaO}$ and $\mathrm{MgO}$. These components, when mixed with water, increase in volume and are transformed into Portlandite and Brucite, which produces breakage and cracking of the cement matrix in the concretes and mortars of which they form part (25-27).

On account of this situation, the stability of the slags has to be tested prior to their use as aggregate in the manufacture of mortars and concretes. Their content of hydratable oxides $(\mathrm{CaO}$ and/or $\mathrm{MgO})$ can produce volumetric instability due to expansion and the tests on the slags will also determine the treatments prior to the weathering process that will help to avoid such behaviour. It is also necessary to evaluate possible reactions of the mineralogical components of the slags, especially reactivity between the alkalis, the silica, and the silicates.

The LFS, because of its nature, presents higher concentrations of $\mathrm{CaO}$ and is the one that, in principle, can cause these types of effects when used as aggregate in the manufacture of mortars and concretes (28). This slag type therefore requires special attention, above all when used as fines in the manufacture of masonry mortars and structural concretes.

The investigation reported in this paper studies the effects of LFS in mortar mixtures, through accelerated expansion tests, both in aqueous solutions and in the presence of expansive compounds.

Cement masonry mortars dosed with various amounts of LFS in partial substitution of a natural siliceous aggregate were designed for the investigation. In this way, the behaviour and the degree of stability of the LFS may be evaluated when the mortars of which they form part are exposed to critical environments, especially due to the presence of humidity and/or aggressive compounds. Moreover, it will also be possible to understand the way in which LFS interacts with the other mortar components.

\section{MATERIALS AND METHODS}

\subsection{Materials}

The mortars were prepared with a Portland cement CEM I 42,5 R, with a density of $3150 \mathrm{~kg} / \mathrm{m}^{3}$, manufactured by Cementos Alfa, from the Cementos Portland Valderribas Group, at its Mataporquera factory (Cantabria-Spain). X-Ray fluorescence testing confirmed that it consisted essentially of $\mathrm{CaO}$ and $\mathrm{SiO}_{2}$, with $346 \mathrm{~m}^{2} / \mathrm{kg}$ of specific surface area according to the Blaine Method.

A washed siliceous sand of sedimentary origin was used as a natural aggregate, commercialized by AIMSA-Arenas Industriales de Montorio at its Montorio factory (Burgos). Analysis of the sand confirmed its high percentage $(98 \%)$ of $\mathrm{SiO}_{2}$.

The LFS was taken from steel refining processes in a Ladle Furnace. In an initial phase, the slag was heaped outside and exposed to weathering processes, 
permitting the hydration of lime $\left(\mathrm{CaO}_{\text {free }}\right)$ and magnesium $\left(\mathrm{MgO}_{\text {free }}\right)$ oxides. In a second phase, it was subjected to a process of disintegration and aging in the laboratory over a longer period of time than five years. In this way, its stabilization was guaranteed and free lime and magnesium oxides were transformed into Portlandite $\mathrm{Ca}(\mathrm{OH})_{2}$ and brucite $\mathrm{Mg}(\mathrm{OH})_{2}$, respectively. It presented a very fine material, of a powdery nature and greyish colour. The main characteristics of LFS are shown on Table 1 and Table 2.

The water used for the formation of the mixtures was taken from the urban mains supply of the city of Burgos-Spain.

\subsection{Mortar mixtures design}

Mortars were designed with different amounts of LFS in substitution of siliceous aggregate, bearing in mind the following considerations:

TABLE 1. Chemical composition of LFS by X-ray fluorescence and other properties

\begin{tabular}{lr}
\hline Blaine value-Surface area & $262-325 \mathrm{~m}^{2} / \mathrm{kg}$ \\
Apparent density & $2637 \mathrm{~kg} / \mathrm{m}^{3}$ \\
$\mathrm{SiO}_{2}$ & $15.7 \%$ \\
$\mathrm{CaO}^{*}$ & $52.0 \%$ \\
$\mathrm{MgO}^{* *}$ & $11.6 \%$ \\
$\mathrm{Al}_{2} \mathrm{O}_{3}$ & $11.8 \%$ \\
$\mathrm{Fe}_{2} \mathrm{O}_{3}$ & $4.1 \%$ \\
$\mathrm{SO}_{3}$ & $2.0 \%$ \\
$\sum \mathrm{Others}_{2}\left(\mathrm{TiO}_{2}+\mathrm{Na}_{2} \mathrm{O}+\mathrm{K}_{2} \mathrm{O}+\right.$ & $2.8 \%$ \\
$\left.\mathrm{MnO}^{2} \mathrm{P}_{2} \mathrm{O}_{5}+\ldots.\right)$ & \\
$* \mathrm{CaO}_{\text {free }}[8.0 \%]$ & \\
$* * \mathrm{MgO}_{\text {free }}[5.0 \%]$ &
\end{tabular}

The ratio of components by weight was $1: 4: \mathrm{W}$, in other words, one part of cement and four parts of aggregate. The amount of water in each of the mixtures was sufficient to obtain a plastic consistency on the flow table $(175 \pm 10 \mathrm{~mm})$, in accordance with European standard EN-1015-3 (29).

The aggregate formed by natural silica sand (NA) and LFS followed the particle size distribution shown in Figure 1. It was prepared by separately weighing out the corresponding amounts of natural sand and LFS in each fraction that is sieved (Figure 2) and by mixing them at the \% indicated in Table 3.

As shown in Table 3, three mortars were designed, MLFS-A, MLFS-B and MLFS-C, with an aggregate composed in each case of variable amounts of siliceous sand (NA) and LFS and a reference mortar M-REF was prepared to study the behaviour of the LFS in the mixtures.

The mortars were prepared by weighing the different sieved fractions. The corresponding amount of Portland cement was added to this mixture. It was all introduced into an automatic Model E-093 mixer and the necessary water was added to produce the desired flow table consistency $(175 \pm 10 \mathrm{~mm})$, mixing the mortar for 90 seconds.

In accordance with the amounts of siliceous sand substituted by LFS, the percentage slag content in each mixture is shown in Table 4.

\subsection{Mortar characterizations}

The aim of the research is to understand the behaviour of cement mortars made with LFS when exposed to humidity and soluble bases; nevertheless, the mortar M-REF and the mortars dosed with different quantities of LFS were previously characterized, as their properties might affect their behaviour under certain conditions of exposure.

The properties of the design mortars were studied in the fresh state, in accordance with the applicable

TABLE 2. Mineralogical composition of LFS by DRX

\begin{tabular}{lll}
\hline Component & & estimated concentration \\
\hline Calcio-olivine; Calcio-olivine, syn & $\mathrm{Ca}_{2}\left(\mathrm{SiO}_{4}\right)$ & High \\
Periclase & $\left(\mathrm{Mg}_{0.974} \mathrm{Fe}_{0.026}\right) \mathrm{O}$ & Moderate \\
Brucite, syn & $\mathrm{Mg}(\mathrm{OH})_{2}$ & Moderate \\
Portlandite, syn & $\mathrm{Ca}(\mathrm{OH})_{2}$ & Low \\
Vaterite, syn & $\mathrm{CaCO}$ & Moderate \\
Calcite, syn & $\mathrm{CaCO}_{3}$ & Moderate \\
Carbon & $\mathrm{C}$ & Moderate \\
Calcium Aluminum Oxide Carbonate Sulfide Hydrate & $\mathrm{Ca}_{4} \mathrm{Al}_{2} \mathrm{O}_{6}\left(\mathrm{CO}_{3}\right)_{0.67}\left(\mathrm{SO}_{3}\right)_{0.33} \cdot 11 \mathrm{H}_{2} \mathrm{O}$ & Traces \\
Mayenite & $\mathrm{Ca}_{12} \mathrm{Al}_{13.86} \mathrm{Fe}_{0.14} \mathrm{O}_{32}(\mathrm{OH})_{2}$ & Low \\
Calcium Aluminum Oxide Carbonate Hydrate & $\mathrm{Ca}_{4} \mathrm{Al}_{2} \mathrm{O}_{6} \mathrm{CO}_{3} \cdot 11 \mathrm{H}_{2} \mathrm{O}$ & Low \\
Calcium Aluminum Iron Silicate Hydroxide & $\mathrm{Ca}_{3} \mathrm{Al} \mathrm{Fe}_{2}\left(\mathrm{SiO}_{4}\right)(\mathrm{OH})_{8}$ & Low \\
\hline
\end{tabular}

Estimated Concentration: High (>30\%), Moderate (10-30\%), Low (2-10\%), Traces $(<2 \%)$ 


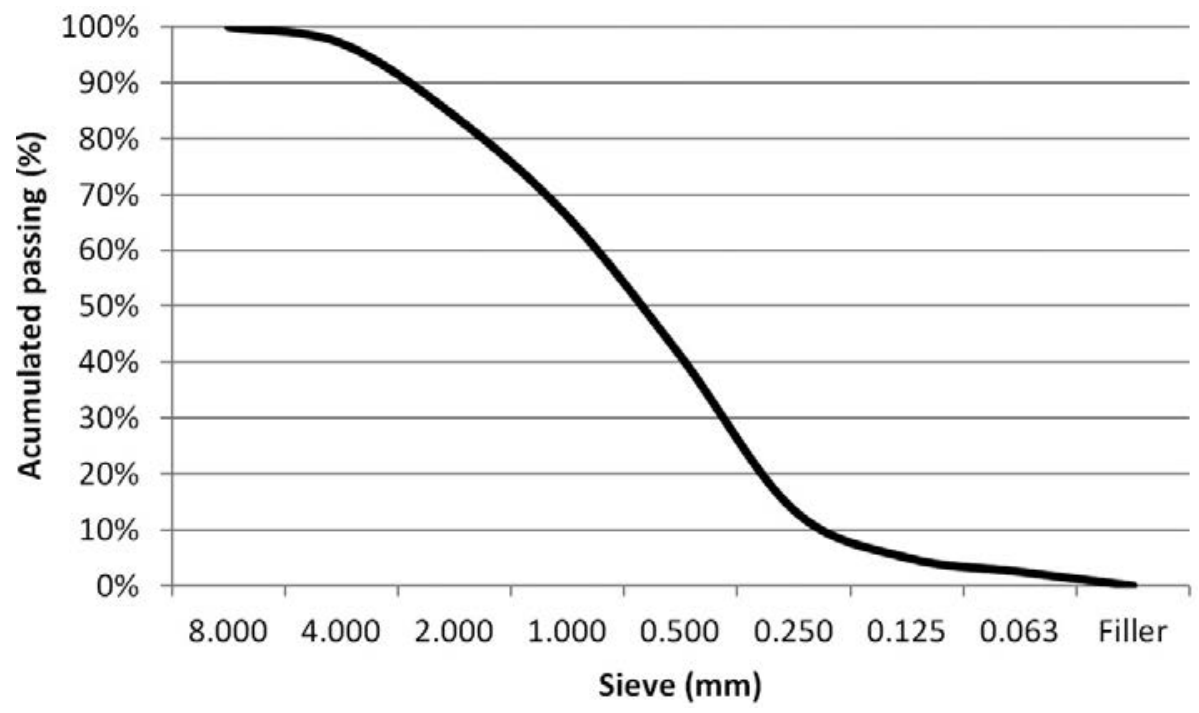

FIgURE 1. Particle size distribution of the aggregates.

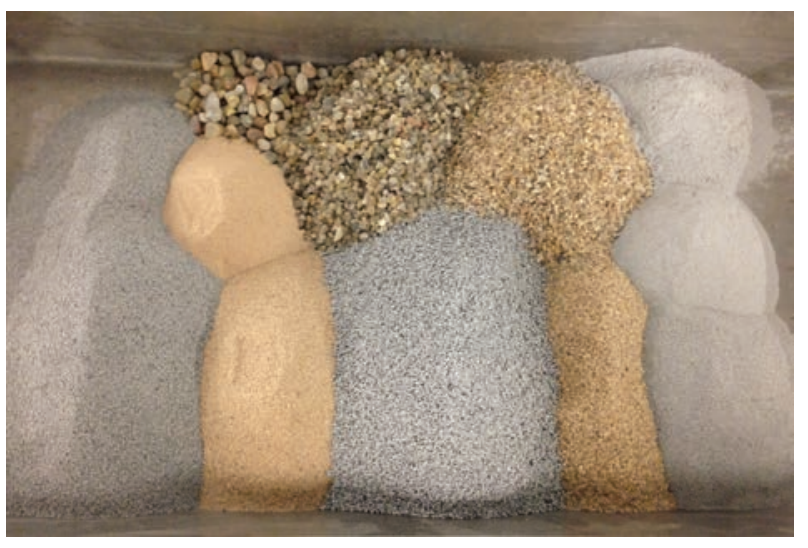

FIGURE 2. Preparation of aggregates.

European standard, determining the following properties for their characterization:

- Flow table consistency, following the procedure determined in standard EN-1015-3 (29).

- Bulk density, in accordance with the specifications established in standard EN-1015-6 (30).

- Determination of air content, following the procedure in standard EN-1015-7 (31).

Samples with dimensions of $40 \times 40 \times 160 \mathrm{~mm}$ were prepared to determine the flexural and compressive strength of the mortar samples. To do so, metallic moulds were filled in two compacted layers followed by 25 normalized and uniformly repeated blows with a hand rammer. They remained for 7 days in the curing chamber at $20^{\circ} \mathrm{C}$ and $95 \%$ relative humidity and were subsequently left for another 21 days, in a chamber at $20^{\circ} \mathrm{C}$ and $65 \%$ relative humidity following the EN 1015-11 (32), until the 28 days of curing were over.

\subsection{Mortars stability}

The mortars in this study were subjected to humidity exposure tests in direct contact with water, with the purpose of provoking the hydration of the $\mathrm{CaO}$ and the $\mathrm{MgO}$ that could have been present in the LFS and to favour their subsequent transformation into Portlandite and Brucite.

Moreover, the possible reactions of the slag components were analysed when in contact with aggressive agents, exposing the specimens to an aqueous medium with high concentrations of sodium hydroxide $(\mathrm{NaOH})$, a very corrosive alkaline substance that is soluble in water.

Samples were prepared in moulds with dimensions of $(25 \times 25 \times 286) \mathrm{mm}$ to test the variations in the specimens in the aforementioned environments, evaluating their expansion and the effects on the material.

\subsubsection{Study of length variations in humid environments or in contact with water.}

UNE 83-318-94 (33) defines the procedure to determine variations in length of mortar specimens prepared, when subjected to accelerated hydration of their components. A series of 3 specimens were prepared in moulds measuring $(25 \times 25 \times 286) \mathrm{mm}$ provided with position markers at both opposing ends. They were cured in a humid chamber for 48 hours, at a temperature of $20^{\circ} \pm 2^{\circ} \mathrm{C}$ and at an environmental humidity of $95 \%$.

Once demoulded, the length of each specimen was measured with an extensometer equipped with a 
TABLE 3. Composition of the aggregate in the design mortars

\begin{tabular}{|c|c|c|c|c|c|c|c|}
\hline \multirow{2}{*}{$\begin{array}{l}\text { Mortar } \\
\text { Sieve }(\mathrm{mm})\end{array}$} & \multirow{2}{*}{$\frac{\text { M-REF }}{\text { NA* }^{*}}$} & \multicolumn{2}{|c|}{ MLFS-A } & \multicolumn{2}{|c|}{ MLFS-B } & \multicolumn{2}{|c|}{ MLFS-C } \\
\hline & & NA & LFS** & NA & LFS & NA & LFS \\
\hline 4.000 & $100 \%$ & $100 \%$ & - & $100 \%$ & - & $100 \%$ & - \\
\hline 2.000 & $100 \%$ & $100 \%$ & - & $100 \%$ & - & $100 \%$ & - \\
\hline 1.000 & $100 \%$ & $100 \%$ & - & $100 \%$ & - & $100 \%$ & - \\
\hline 0.500 & $100 \%$ & $50 \%$ & $50 \%$ & $25 \%$ & $75 \%$ & - & $100 \%$ \\
\hline 0.250 & $100 \%$ & $50 \%$ & $50 \%$ & $25 \%$ & $75 \%$ & - & $100 \%$ \\
\hline 0.125 & $100 \%$ & $50 \%$ & $50 \%$ & $25 \%$ & $75 \%$ & - & $100 \%$ \\
\hline 0.063 & $100 \%$ & - & $100 \%$ & - & $100 \%$ & - & $100 \%$ \\
\hline Filler & $100 \%$ & - & $100 \%$ & - & $100 \%$ & - & $100 \%$ \\
\hline
\end{tabular}

*NA: Natural aggregates

**LFS: Ladle Furnace Slag

TABLE 4. Proportion of slag in the aggregate of the design mortars

\begin{tabular}{lccccc}
\hline & & & \multicolumn{2}{c}{ Aggregates (g) } & \multirow{2}{*}{ \%(LFS/ } \\
\cline { 4 - 5 } Mortar & CEM (g) & W (l) & NA & LFS & Aggregates) \\
\hline M-REF & 400 & 259 & 1600 & - & 0.0 \\
MLFS-A & 400 & 405 & 1032 & 568 & 35.50 \\
MLFS-B & 400 & 475 & 788 & 812 & 50.75 \\
MLFS-C & 400 & 535 & 544 & 1056 & 66.00 \\
\hline
\end{tabular}

previously calibrated dial gauge, and the specimens were completely immersed in water at a temperature of $20^{\circ} \mathrm{C}$, taking daily readings of their lengths up until 50 days of age.

The change in length was expressed by the percentage increase or decrease of the largest size of the test specimen, adjusted to $0.001 \%$, in accordance with the following expression [1]:

$$
\varepsilon_{d}=100 \frac{l_{f}-l_{0}}{l_{0}}
$$

where,

$\varepsilon_{\mathrm{d}}=$ percentage change in length

$1_{\mathrm{f}}=$ measured length at each test age

$1_{0}=$ Initial length of the measured when removing the specimen from its mould

\subsubsection{Study of the potential alkali-silica and alkali- silicate reactivity of the slag aggregates.}

The reference standard to study this behaviour is UNE 146508 EX (34). The potential alkali-silica and alkali-silicate reactivity of the mineralogical components of the LFS were studied through this test, with which the final behaviour of the mortar mix may be predicted. To do so, three specimens with dimensions of $(25 \times 25 \times 286) \mathrm{mm}$ were made, also with two position markers on both faces for their positioning in the extensometer, and then cured in a humidity chamber for 72 hours.

Subsequently, the initial length of each specimen was measured and arranged in containers with sufficient water so that they were completely immersed. The containers were then placed in a stove at $80^{\circ} \mathrm{C} \pm 2.0^{\circ} \mathrm{C}$ for $24 \mathrm{~h} \pm 2 \mathrm{~h}$. Once that time had elapsed, the specimens were extracted one by one from the water, their surfaces wiped with a dry cloth, and their lengths measured with an extensometer equipped with a previously calibrated dial gauge $\left(\mathrm{L}_{0}\right)$.

Afterwards, the samples were totally submerged in a solution of $\mathrm{NaOH} 1 \mathrm{~N}$ previously heated to $80^{\circ} \mathrm{C} \pm 1^{\circ} \mathrm{C}$. An amount of 40.0 gr de $\mathrm{NaOH}$ was dissolved in distilled water to obtain the solution until a volume of $1000 \mathrm{ml}$ was obtained. Then, the containers were placed in a stove at $80^{\circ} \pm 2^{\circ} \mathrm{C}$ and length measurements were taken with the specimens exposed to alkalinity. The results were obtained in accordance with the following expression [2]:

$$
\% \text { Expansion }=100 \frac{L_{n}-L_{0}}{L_{c}}
$$

where,

$\mathrm{L}_{\mathrm{n}}=$ Specimen length after treatment with $\mathrm{NaOH}$ at $80 \pm 2^{\circ} \mathrm{C}$

$\mathrm{L}_{0}=$ Specimen length after treatment with water at $80 \pm 2^{\circ} \mathrm{C}$

$\mathrm{L}_{\mathrm{c}}=$ Calibrated length

\section{RESULTS AND DISCUSSION}

\subsection{Mortars characterization}

The properties of the mortars in fresh state are shown in Table 5.

Having completed the characterization tests of the mortars in the fresh state, it may be seen that the 
progressive substitution of natural siliceous aggregate for LFS produced an important increase in the water/cement (w/c) ratio; the MLFS-C mortar, consisting of $66 \%$ LFS, had practically twice as much

TABLE 5. Properties of mortars in fresh state

\begin{tabular}{lccc}
\hline Mortar & w/c & $\begin{array}{c}\text { Air } \\
\text { content (\%) }\end{array}$ & $\begin{array}{c}\text { Bulk density of fresh } \\
\text { mortar }\left(\mathbf{k g} / \mathbf{m}^{3}\right)\end{array}$ \\
\hline M-REF & 0.6475 & 05.8 & 2165 \\
MLFS-A & 1.0500 & 15.0 & 1827 \\
MLFS-B & 1.1875 & 15.0 & 1768 \\
MLFS-C & 1.3375 & 14.5 & 1749 \\
\hline
\end{tabular}

water, with regard to the reference mortar specimen, M-REF, manufactured with only natural siliceous aggregate (Figure 3 ).

The high demand of mixing water required in the mortars dosed with LFS determined a significant increase in their content of occluded air. It may be seen that regardless of the quantity of slag substituted by the natural siliceous aggregate, the occluded air reached a value of around $15 \%$, practically twice that registered in the M-REF reference mortar manufactured with natural siliceous aggregate (Figure 4).

The validation of these results is evident from the apparent density values of the mortars in the fresh state; a progressive reduction may be observed
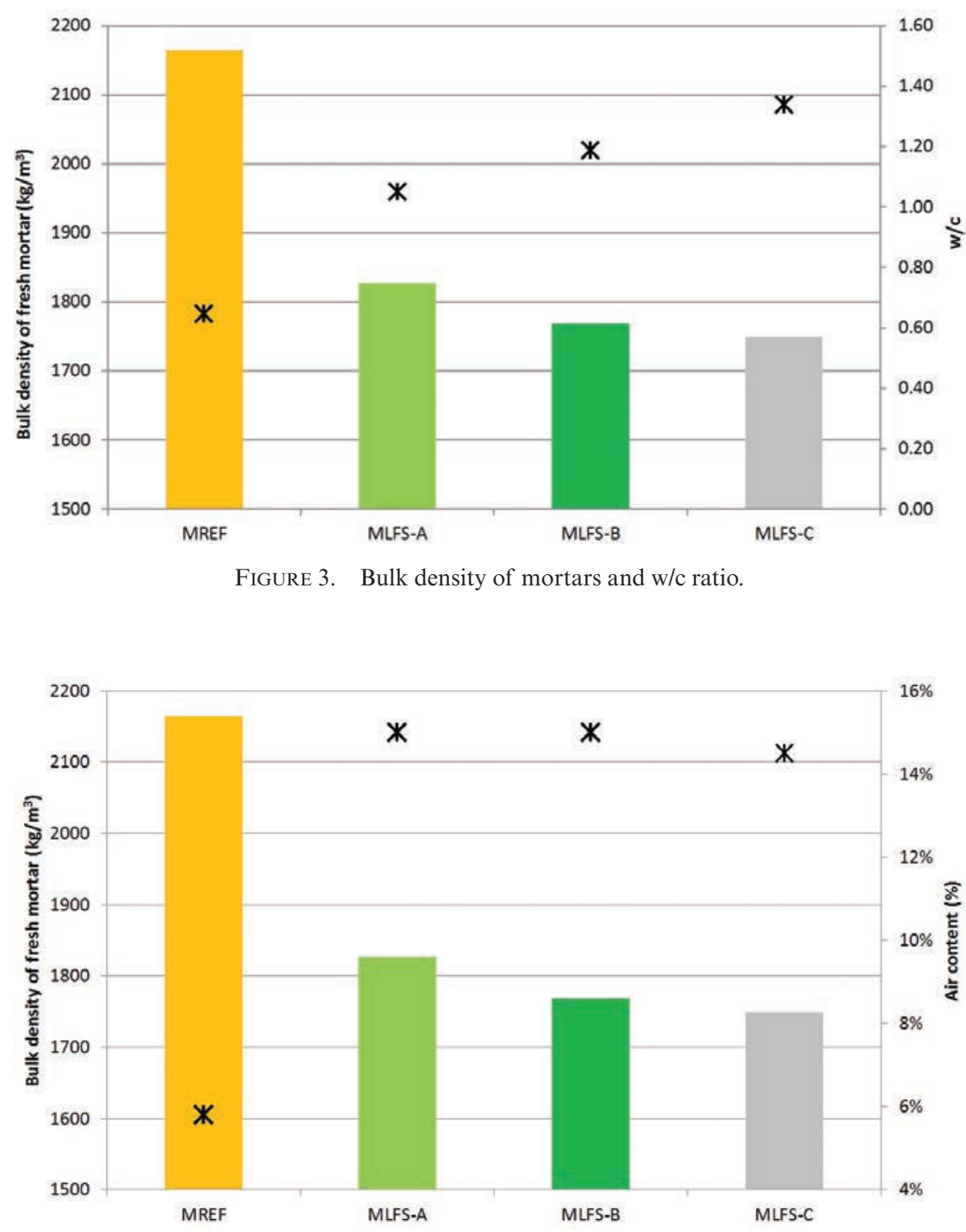

FIGURE 4. Bulk density of mortars and air content. 
proportionate with the increase in the amount of sand substituted by LFS, with a difference between the M-REF mortar and the MLFS-C mortar of 19\%.

The results obtained in the characterization tests showed that the mortars dosed with LFS were more porous, which affected their mechanical properties and their compactness, with better defined interstitial structures, facilitating the intake of water into the material and implying a potential risk for their durability. The mechanical strength results obtained are shown in Table 6.

The results obtained in the test of flexural and compressive strength showed that the mortars reduced their strength as the amount of LFS added to the mixtures increased. As may be seen in Table 5 and Figure 5, the incorporation of LFS produced a significant reduction in mechanical strengths, both

TABLE 6. Mechanical strength of mortars at 28 Days

\begin{tabular}{lcc}
\hline Mortar & $\begin{array}{c}\text { Flexural } \\
\text { Strength (N/mm }\end{array}$ & $\begin{array}{c}\text { Compressive } \\
\text { Strength }\left(\mathbf{N} / \mathbf{m m}^{2}\right)\end{array}$ \\
\hline M-REF & 5.63 & 31.83 \\
MLFS-A & 3.94 & 12.27 \\
MLFS-B & 4.08 & 11.50 \\
MLFS-C & 3.69 & 11.33 \\
\hline
\end{tabular}
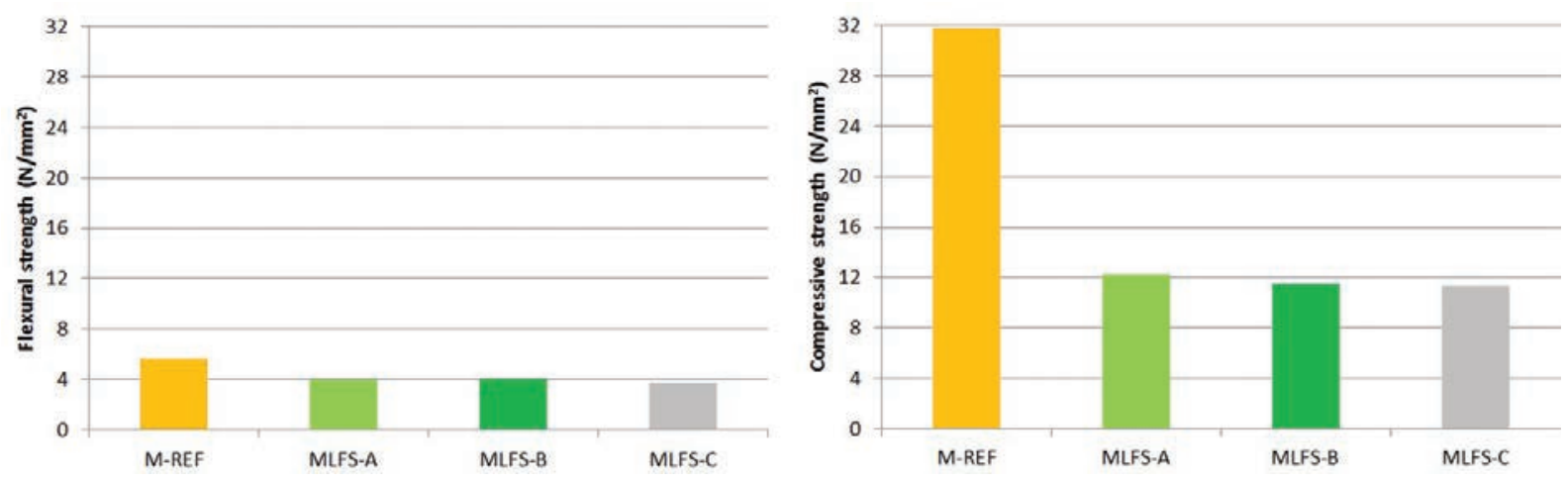

FIGURE 5. Flexural and compressive strength of mortars.

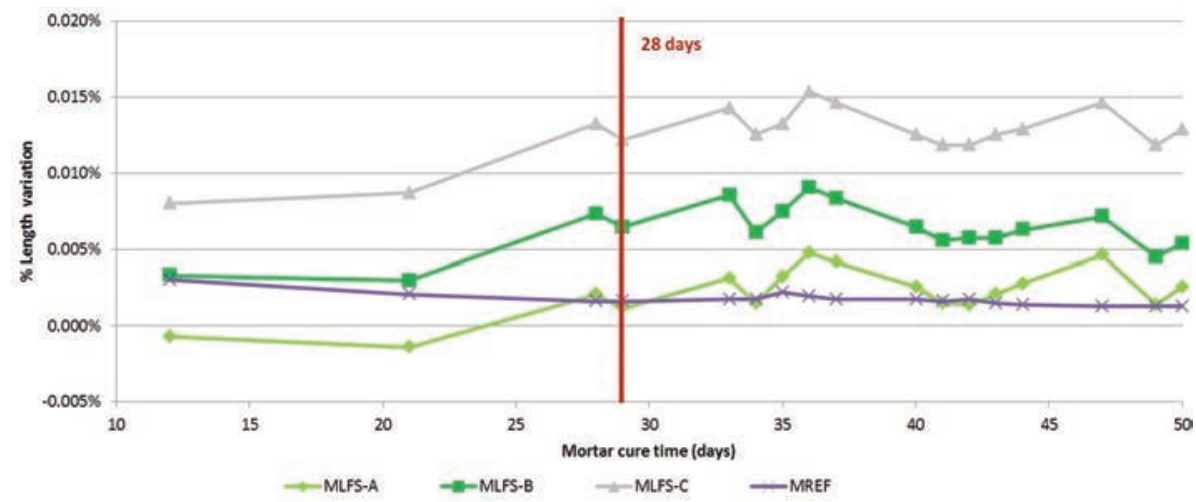

FIGURE 6. Dimensional evolution of the specimens exposed to humidity. 
There are previous studies that have analysed the dimensional stability of the mortars manufactured with LFS subjected to durability and accelerated ageing tests, such as successive states of humiditydryness $(35-36)$. In these cases, the mortars have curing ages higher than 28 days, in other words, they are set and hardened. On the contrary, the mortars in the present study underwent dimensional stability tests once the specimens had been demoulded, in other words, the mortar sets and hardens while submerged in water at $20^{\circ} \mathrm{C}$.

The stability of mortars manufactured with LFS is guaranteed, subject to previous weathering and conditioning of the LFS. As is well known (Table 1), LFS largely consists of calcium oxide $(\mathrm{CaO})$, silica $\left(\mathrm{SiO}_{2}\right)$, magnesium $(\mathrm{MgO})$, and aluminium oxide $\left(\mathrm{Al}_{2} \mathrm{O}_{3}\right)$, such that the presence of free lime $(\mathrm{CaO})$ and periclase $(\mathrm{MgO})$ can give rise to hydration and carbonation reactions in subsequent phases. This behaviour depends to a great extent on the chemical, mineralogical, and microstructural properties of the material (37).

Additionally, in our case, it is worth highlighting that the slag has calcium and magnesium oxides that are perfectly hydrated before the preparation of the mortars, a circumstance that implies good stability when they are in contact with water (Figure 7).

Visual inspection concluded that no surface damage was appreciated such as fissures, flaking, and cracking. The edges remained in place with no material loss

Nevertheless, it would be necessary to conduct a more complete study of the behaviour of the design mortars when the environmental humidity that they withstand or to which they are exposed occurs at low and even at icy temperatures. Due to their high porosity, it is likely that the expansive effect of the frozen water will affect the dimensional stability of the specimens and the cohesion of the cement matrix.

\subsection{Study of the potential alkali-silica and alkali- silicate reactivity of the slag aggregates}

The results obtained in the study of LFS mortar behaviour in the expansivity test in alkaline environments are especially critical after subjecting the material to the action of sodium hydroxide $(\mathrm{NaOH}$ $1 \mathrm{~N})$ dissolved in water at $80^{\circ} \mathrm{C}$.

As may be seen in Figure 8, the mortars dosed with LFS have undergone significant expansion, which is greater in proportion with the amount of siliceous sand that is substituted by slag.

In the MLFS-B and MLFS-C mortars, the records show a high expansive effect when the slag components react with sodium hydroxide $\mathrm{NaOH}$ $1 \mathrm{~N}$, breaking the structure of the cement matrix after two days of exposure. The MLFS-A mortar, with the lowest quantity of LFS in its dosing maintained a degree of stability in the first few days, however, the expansion of the specimens at 7 days of exposure to an alkaline environment was in excess of the average expansion measured by the extensometer dial gauge $(5 \mathrm{~mm})$, over the maximum limit established in standard UNE 83-318-94. On the contrary, the reference mortar M-REF showed

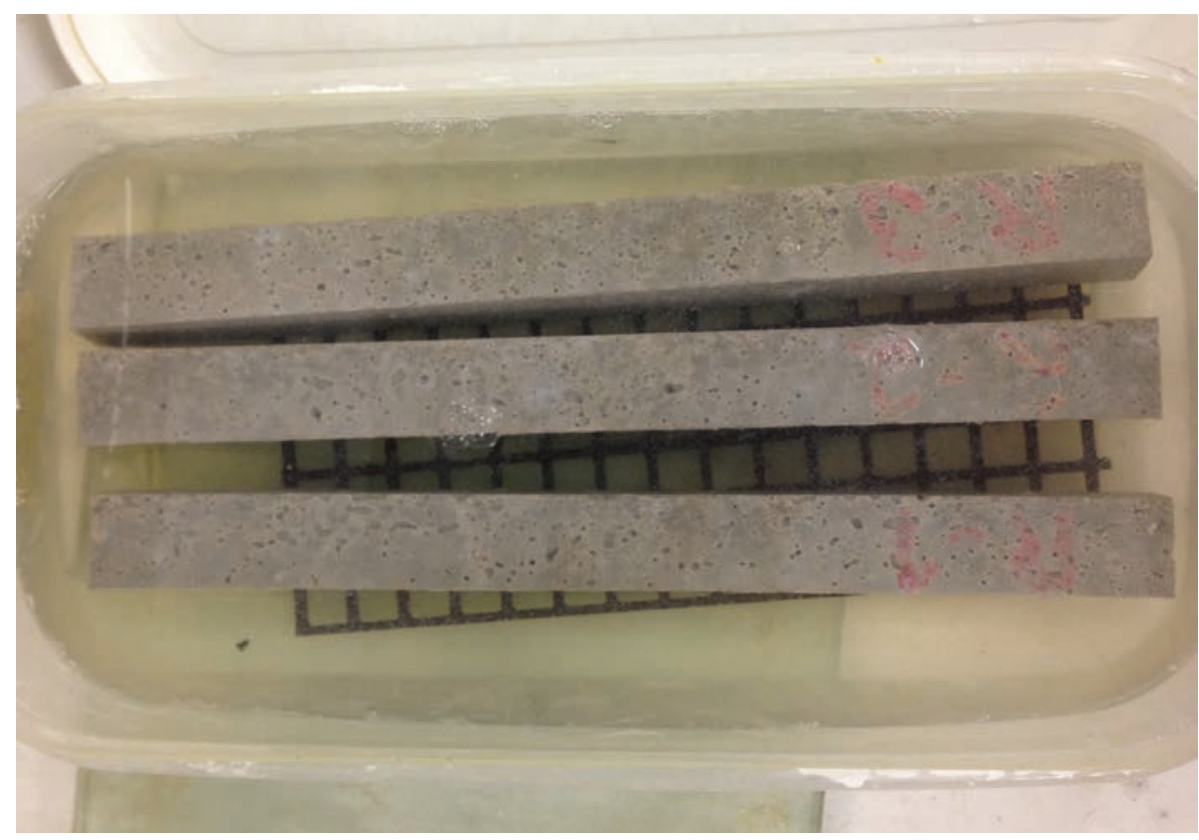

Figure 7. Samples of mortars immersed in water at $20^{\circ} \mathrm{C}$. 


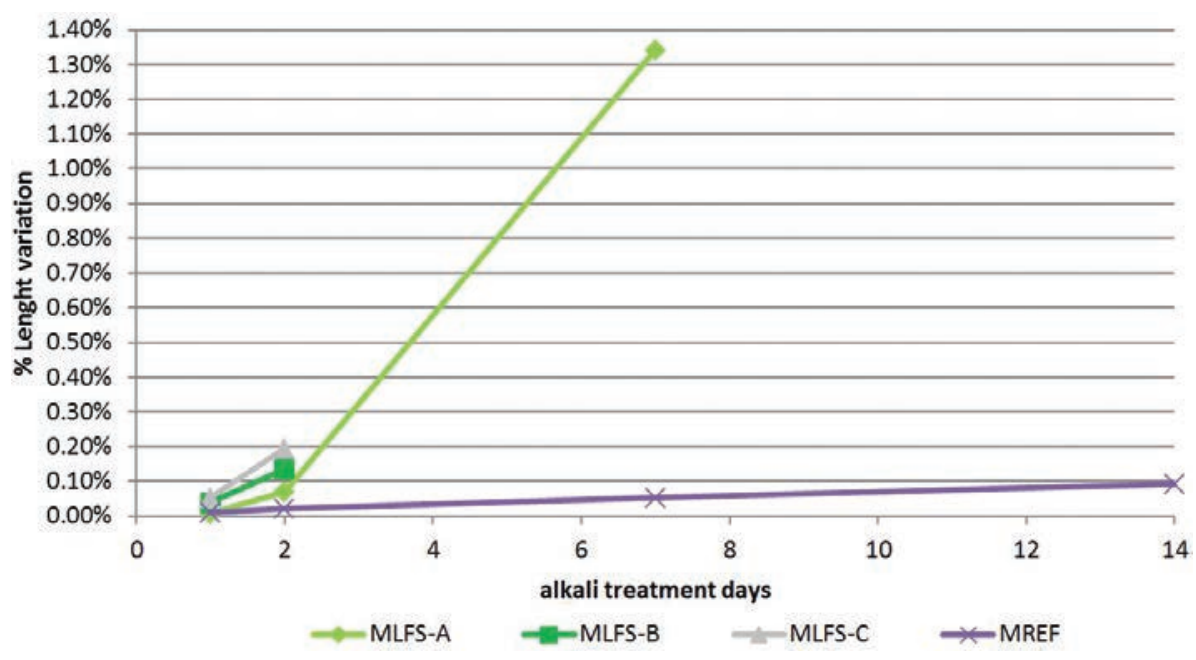

Figure 8. Dimensional evolution of the specimens exposed to the action of $\mathrm{NaOH}$.

a normal evolution in its behaviour, as it was not over $0.10 \%$ established as the limit by the norm.

The external appearances of samples subjected to the test are shown in Figure 9. Flaking and material loss, the appearance of craters and crumbling were appreciable.

The mortar microstructures exposed to the action of sodium hydroxide $(\mathrm{NaOH})$ were tested to round off the study, observing the effect produced on the mortar components, especially in the cementitious matrix. The mortars were analysed under the scanning electron microscope (SEM) to complete the study.

The mortar samples were dried and covered by low vacuum (gold) sputter coating with an EMITECH K550X Sputter Coater, at a current of $30 \mathrm{~mA}$ over 2 minutes, in an Argon atmosphere. Subsequently, the surfaces were analysed by scanning electronic microscopy Model JEOL JSM-6460-LV with an INCA elemental X-Ray analysis system, at an acceleration voltage of $0.2-30 \mathrm{KV}$. The microscope was equipped with a secondary electron (SE) detector that generates topographic images of the sample surface. The microscope has an Energy Dispersive $\mathrm{X}$-Ray $\left(\mathrm{X}-\mathrm{Max}^{\mathrm{N}}\right)$ system for the analysis of the elemental chemical composition of the mortars.

In the microscope images, the bond break between the cement matrix and the aggregate is checked in all mortars dosed with LFS (Figure 10).

As may be seen in Figure 8, the aggregate material dosed in the MREF is not a reactive aggregate, however, when this mortar is analysed under the microscope, typical "rose-petal" formations may be observed (Figure 11), due to the reaction of sodium hydroxide $(\mathrm{NaOH})$ with the crystalline structures of the siliceous fines (38). Nevertheless, these crystalline structures did not appear in the mortars manufactured with LFS, when analysed under scanning electron microscopy.

This evaluation method is especially destructive and unsuitable to analyse the behaviour of mortars dosed with LFS. The expansive reaction of sodium hydroxide probably masks other possible reactions of the mortar components. In the reactivity test,
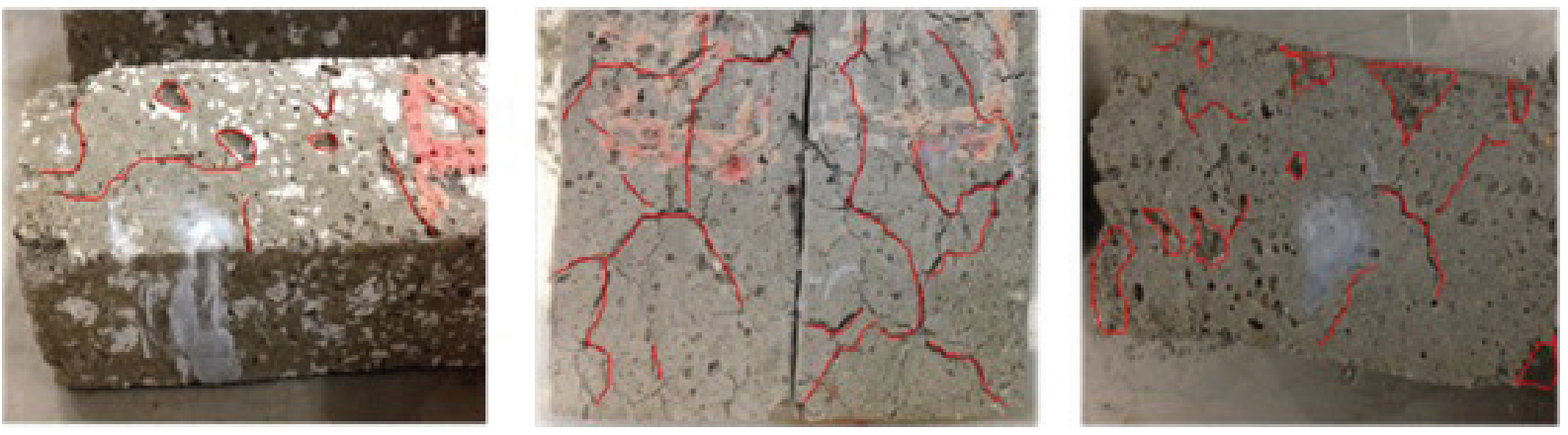

FIGURE 9. Cracks and fissure in mortars manufactured with LFS (MLFS-A, MLFS-B AND MFLS-C, respectively). 


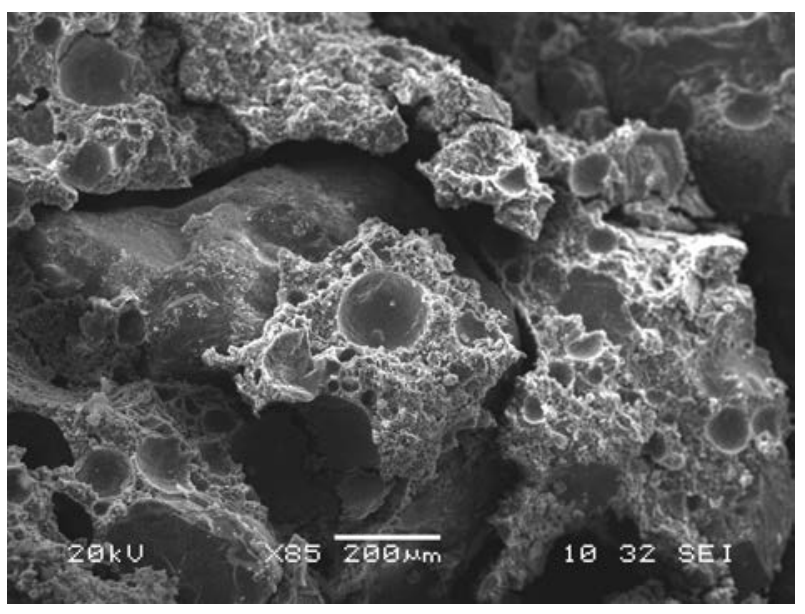

FIGURE 10. Break of the bond between cement matrix-aggregate MLFS-A.

in addition to $\mathrm{NaOH} 1 \mathrm{~N}$, there is a temperature facture, because the specimens were submerged in water at $80^{\circ} \mathrm{C}$. Mortar specimens aged over 28 days were submerged in the water at $80^{\circ} \mathrm{C}$, in order to test the effect of the water at this temperature on the specimens. After 15 days submerged in water at $80^{\circ} \mathrm{C}$, a generalised deterioration was observed, with evident signs of expansion and breakage of the material (Figure 12).

Cement matrix of MLFS-A and MLFS-C were observed with the scanning electron microscope (SEM) (Figure 13). As may be confirmed, it is possible to observe high concentrations of crystalline needle-like structures located inside the pores, especially concentrated around the cracks. If these crystalline structures are analysed by dispersive energy X-Rays

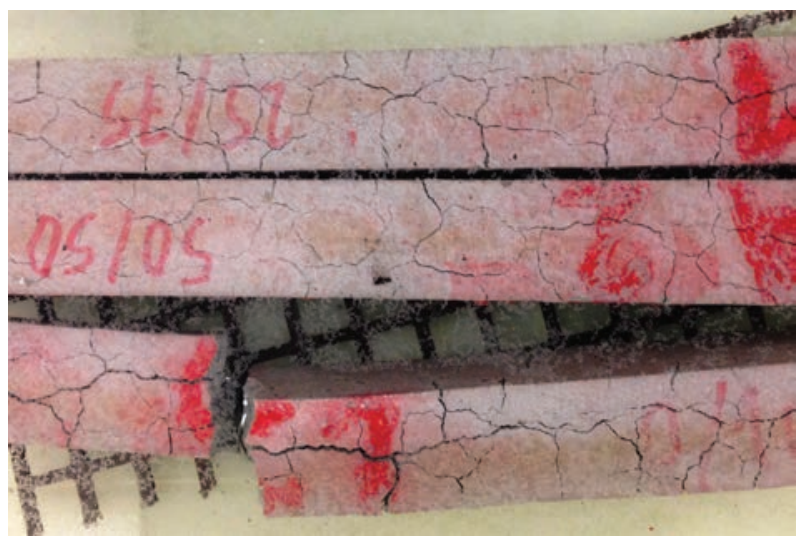

Figure 12. Appearance after immersion in water at $80^{\circ} \mathrm{C}$. From up to down MLFS-A; MLFS-B; MLFS-C.

(EDS), the elemental components obtained have concentrations of $\mathrm{S}$ and $\mathrm{Al}$, compatible with sulphates and sulpho-aluminates expansive compounds.

Matrix breakage (disruptive processes) may be confirmed, due to the presence these acicular structures accumulated at the lowest point in small pores. The appearance of this type of compound may be deduced by the presence of mineralogical structures associated with expansive hydrated and/or carbonated elements of crystalline phases with the presence of aluminium, magnesium, and/or calcium. The reaction is favoured by the presence of humidity and high temperature (39-40).

As has been confirmed, the structure of the specimens broke up after exposure to the action of water at a high temperature $\left(>80^{\circ} \mathrm{C}\right)$, producing loss of internal cohesion and destruction, especially in the aggregate-paste cement interface.
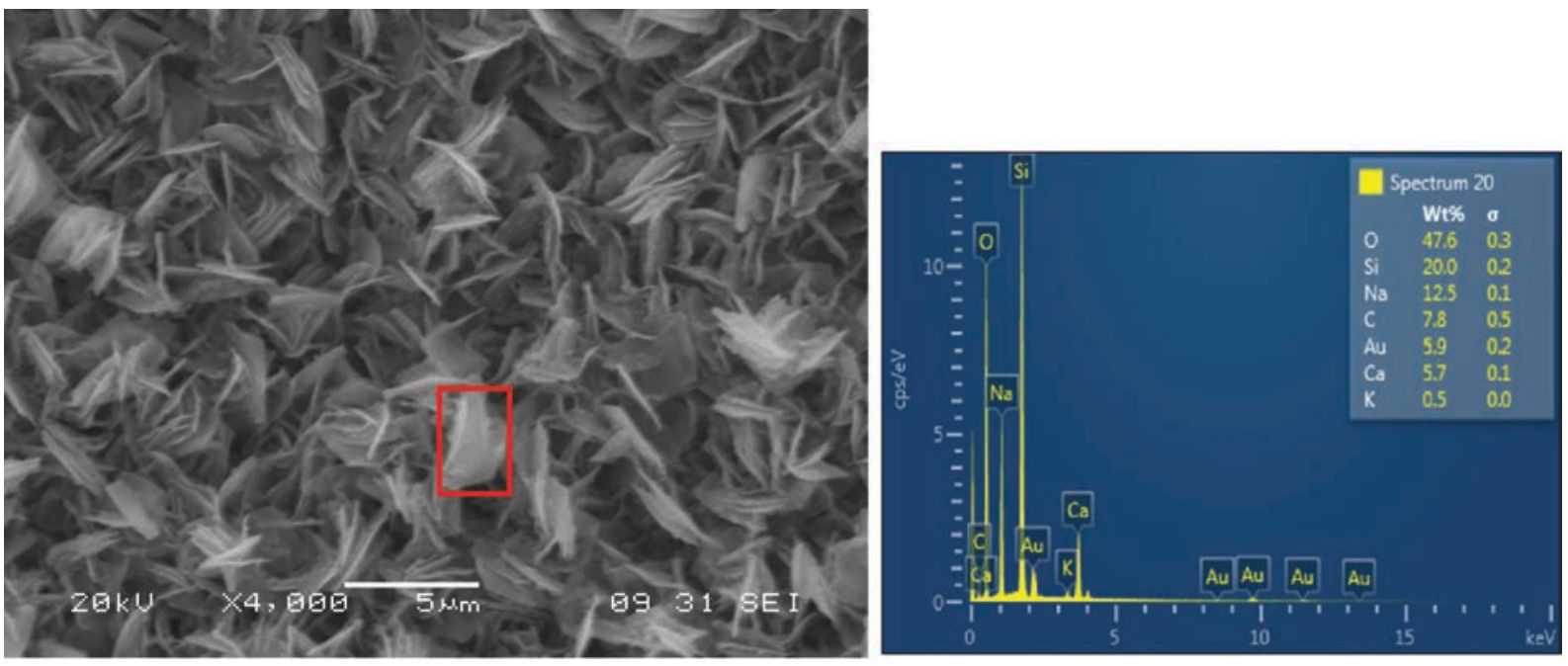

Figure 11. Gels found on the surface. Rose petals gel M-REF. 

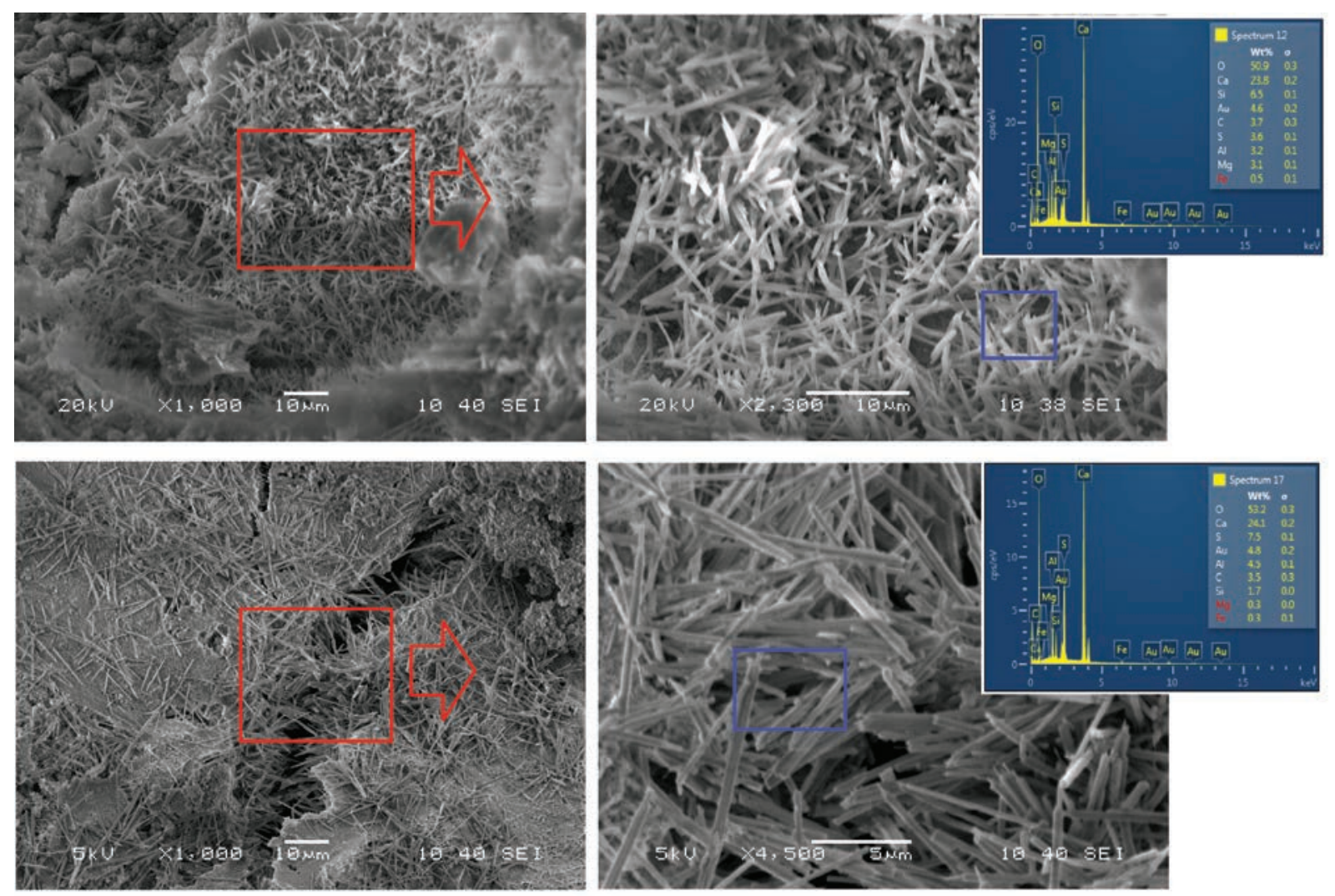

FIgURE 13. Acicular structures. up: MLFS-A; down: MLFS-C.

Although the LFS is not a reactive aggregate as such, in the presence of humidity and high temperatures $\left(>80^{\circ} \mathrm{C}\right)$, it showed an expansive behaviour, so its use is not recommended in conglomerates exposed to those environmental conditions (high humidity and temperature).

\section{CONCLUSIONS}

The present work has as objective to determine the expansive behaviour that is produced in masonry mortars designed with LFS, when exposed to especially aggressive environmental conditions. Having analysed the results of the tests in the study, the conclusions are the following:

- The masonry mortars designed with LFS showed good dimensional stability when exposed to humid environments and with an ambient temperature that was never in excess of $20^{\circ} \mathrm{C}$.

Despite its high porosity, the structure of the mortars remained intact, hence it may be affirmed that LFS slag is properly stabilized and that it has no free unhydrated expansive components $(\mathrm{CaO}$ and $\mathrm{MgO})$.

- On the contrary, the mortars prepared with LFS underwent expansive change in the presence of
$\mathrm{NaOH} 1 \mathrm{~N}$ dissolved in water at a temperature of $80^{\circ} \mathrm{C}$, producing generalized degradation of the internal structure of the mortars and their total destruction.

Having analysed the samples with scanning electron microscopy, neither crystalline structures nor characteristics of alkali-aggregate reactivity (rose-petal formations) were observed, for which reason it was concluded that LFS slag is not a reactive aggregate.

- The mortars designed with LFS submerged in water at a temperature of $80^{\circ} \mathrm{C}$, presented an unstable behaviour, because of the multiple points of degradation in their internal structure. The observation of the mortar samples by means of scanning electron microscopy (SEM) revealed an abundant presence of crystalline acicular structures, especially in the mortar cavities. Those structures explain the generalized destruction of the material, because of the expansive effect of this sulphates and sulpho-aluminates compounds.

The conclusion drawn from the above analysis is that an upper threshold for LFS in the design of masonry mortars is worth considering, especially when they are exposed to humid environments at 
high temperatures, thereby avoiding possible adverse effects on the structure of the material.

\section{REFERENCES}

1. Kirchherr, J.; Reike, D.; Hekkert, M. (2017) Conceptualizing the circular economy: An analysis of 114 definitions. Resour. Conserv. Recy. 127, 221-232. https://doi.org/10.1016/j. resconrec.2017.09.005.

2. Suárez, P. Á.; Marcote, P. V.; Emilia, I. (2016) Hacia el desarrollo sostenible en el tercer milenio. Análisis de una estrategia educativa para la concienciación y la estimulación de conductas sostenibles. Paradigma, 27, 55-72.

3. European Commission (2014) Communication from the Commission to the European Parliament, the Council, the European Economic and Social Committee and the Committee of the Regions. Brussels.

4. Potting, J.; Nierhoff, N.; Montevecchi, F.; Antikainen, R.; Colgan, S.; Hauser, A.; Hanemaaijer, A. (2017) Input to the European Commission from European EPAs about monitoring progress of the transition towards a circular economy in the European Union.

5. Olmez, G. M.; Dilek, F. B.; Karanfil, T.; Yetis, U. (2016) The environmental impacts of iron and steel industry: a life cycle assessment study. J. Clean. Prod. 130, 195-201. https://doi.org/10.1016/j.jclepro.2015.09.139.

6. WSO (2014). World Steel Association website: www.worldsteel.org. Retrieved on May 2018.

7. Piatak, N. M.; Parsons, M. B.; Seal, R. R. (2015) Characteristics and environmental aspects of slag: A review. Appl. Geochem. 57, 236-266. https://doi.org/10.1016/j.apgeochem.2014.04.009.

8. Motz,H.; Geiseler, J. (2001) Products of steel slags: an opportunity to save natural resources. Waste Manage. 21, 285-293. http://dx.doi.org/10.1016/S0956-053X(00)00102-1.

9. Lopez, F. (1997). Physico-chemical and mineralogical properties of EAF and AOD slags. In EOSC'97: $2^{\text {nd }}$ European Oxygen Steelmaking Congress, 417-426.

10. Frías, M.; Rojas, M. S. de.; Uría, A. (2002) Study of the instability of black slags from electric arc furnace steel industry. Mater. Construcc. 52, 79-83. http://dx.doi.org/10.3989/ mc.2002.v52.i267.328.

11. Manso, J. M.; Gonzalez, J. J.; Polanco, J. A. (2004) Electric arc furnace slag in concrete. ASCE J. Mater. Civ. Eng. 16, 639-645. https://doi.org/10.1061/(ASCE)08991561(2004)16:6(639).

12. Rodriguez, Á.; Manso, J. M.; Aragón, Á.; Gonzalez, J. J. (2009) Strength and workability of masonry mortars manufactured with ladle furnace slag. Resour. Conserv. Recy. 53, 645-651. https://doi.org/10.1016/j.resconrec.2009. 04.015 .

13. Kanagawa, A.; Kuwayama, T. (1997) The improvement of soft clayey soil utilizing reducing slag produced from electric arc furnace. Denki Seiko (Electric Furnace Steel) (Japan), 68, 261-267.

14. Ahmedzade, P.; Sengoz, B. (2009). Evaluation of steel slag coarse aggregate in hot mix asphalt concrete. J. Hazar. Mater. 165, 300-305. https://doi.org/10.1016/j.jhazmat. 2008.09.105.

15. Kandhal, P.; Hoffman, G. (1997) Evaluation of steel slag fine aggregate in hot-mix asphalt mixtures. Transportation Research Record. Journal of the Transportation Research Board 1583, 28-36. https://doi.org/10.3141/1583-04.

16. Biskri, Y.; Achoura, D.; Chelghoum, N.; Mouret, M. (2017) Mechanical and durability characteristics of High Performance Concrete containing steel slag and crystalized slag as aggregates. Constr. Build. Mater. 150, 167-178. https://doi.org/10.1016/j.conbuildmat.2017.05.083.

17. Vijayaraghavan, J.; Jude, A. B.; Thivya, J. (2017) Effect of copper slag, iron slag and recycled concrete aggregate on the mechanical properties of concrete. Resour. Policy 53, 219-225. https://doi.org/10.1016/j.resourpol.2017.06.012.
18. Wijayasundara, M.; Mendis, P.; Crawford, R. H. (2017) Methodology for the integrated assessment on the use of recycled concrete aggregate replacing natural aggregate in structural concrete. J. Clean. Prod. 166, 321-334. https:// doi.org/10.1016/j.jclepro.2017.08.001.

19. Santamaría-Vicario, I.; Rodríguez, A.; Gutiérrez-González, S.; Calderón, V. (2015) Design of masonry mortars fabricated concurrently with different steel slag aggregates. Constr. Build. Mater. 95, 197-206. https://doi.org/10.1016/j. conbuildmat.2015.07.164.

20. Santamaría-Vicario, I.; Rodríguez, A.; Junco, C.; GutiérrezGonzález, S.; Calderón, V. (2016) Durability behavior of steelmaking slag masonry mortars. Mater. Design. 97, 307-315. https://doi.org/10.1016/j.matdes.2016.02.080.

21. Rodríguez, A.; Gutiérrez-González, S.; Horgnies, M.; Calderón, V. (2013). Design and properties of plaster mortars manufactured with ladle furnace slag. Mater. Design. 52, 987-994. https://doi.org/10.1016/j.matdes. 2013.06.041.

22. Manso, J. M.; Losañez, M.; Polanco, J. A.;Gonzalez, J. J. (2005) Ladle furnace slag in construction. $A S C E$ J. Mater. Civ. Eng. 17, 513-518. https://doi.org/10.1061/ (ASCE)0899-1561(2005)17:5(513).

23. Gahan, C. S.; Cunha, M. L.; Sandström, Å. (2009) Comparative study on different steel slags as neutralizing agent in bioleaching. Hydrometallurgy 95, 190-197. https:// doi.org/10.1016/j.hydromet.2008.05.042.

24. Kourounis, S.; Tsivilis, S.; Tsakiridis, P. E.; Papadimitriou, G. D., Tsibouki, Z. (2007) Properties and hydration of blended cements with steelmaking slag. Cem. Concr. Res. 37, 815-822. https://doi.org/10.1016/j.cemconres.2007. 03.008.

25. Arribas, I.; Vegas, I.; San-Jose, J. T: Manso, J. M. (2014) Durability studies on steelmaking slag concretes. Mater. Design. 63, 168-176. https://doi.org/10.1016/j.matdes.2014. 06.002 .

26. Wang, Q.; Wang, D.; Zhuang, S. (2017) The soundness of steel slag with different free $\mathrm{CaO}$ and $\mathrm{MgO}$ contents. Constr. Build. Mater. 151, 138-146. https://doi.org/10.1016/j. conbuildmat.2017.06.077.

27. Kuo, W. T.; Shu, C. Y.; Han, Y. W. (2014) Electric arc furnace oxidizing slag mortar with volume stability for rapid detection. Constr. Build. Mater. 53, 635-641. https://doi. org/10.1016/j.conbuildmat.2013.12.023.

28. Polanco, J. A.; Manso, J. M.; Setién, J.; González, J. J. (2011) Strength and Durability of Concrete Made with Electric Steelmaking Slag. ACI Mater. J. 108, 196-203.

29. EN 1015-3:2000. Methods of test for mortar for masonry. Part 3: Determination of consistence of fresh mortar (by flow table).

30. EN 1015-6:1999/A1:2007. Methods of test for mortar for masonry-Part 6: Determination of bulk density of fresh mortar.

31. EN 1015-7:1999. Methods of test for mortar for masonryPart 7: Determination of air content of fresh mortar.

32. EN 1015-11:2000. Methods of test for mortar for masonry. Part 11: Determination of flexural and compressive strength of hardened mortar.

33. UNE 83-318-94:1994 Concrete tests. Determination of the length changes.

34. UNE 146508 EX: 1999 Test for aggregates. Determination of the alkali-silica and alkali-silicate potential reactivity of aggregates. Accelerated mortar bar test

35. Manso, J. M.; Rodríguez, Á; Aragón, Á. Gonzalez, J. J. (2011) The durability of masonry mortars made with ladle furnace slag. Constr. Build. Mater. 25, 3508-3519. https://doi.org/10.1016/j.conbuildmat.2011.03.044.

36. Herrero, T.; Vegas, I. J.; Santamaría, A.; San-José, J. T.; Skaf, M. (2016) Effect of high-alumina ladle furnace slag as cement substitution in masonry mortars. Constr. Build. Mater. 123, 404 413. https://doi.org/10.1016/j.conbuildmat. 2016.07.014.

37. Setién J.; Hernández D.; Gonzalez J. J. (2009) Characterization of ladle furnace basic slag for use as a construction 
material. Constr. Build. Mater. 23, 1788-1794. https://doi. org/10.1016/j.conbuildmat.2008.10.003

38. Gadea, J.; Soriano, J.; Martín, A.; Campos, P. L.; Rodríguez, A.; Junco, C.; Calderón, V. (2010) The alkali-aggregate reaction for various aggregates used in concrete. Mater. Construc. 60, 69-78. https://doi.org/10.3989/mc.2010.48708.
39. Taylor, H.F.; Famy, C.; Scrivener, K. (2001) Delayed ettringite formation. Cement and Concrete Research, 31, 683-693. https://doi.org/10.1016/S0008-8846(01)00466-5.

40. Collepardi, M. (2003) A state-of-the-art review on delayed ettringite attack on concrete. Cement Concrete Comp., 25, 401-407. https://doi.org/10.1016/S0958-9465(02)00080-X 